\title{
Environmental influences on the occurrence of coastal sharks in estuarine waters
}

\author{
John Froeschke', Gregory W. Stunz ${ }^{1, *}$, Mark L. Wildhaber ${ }^{2}$ \\ ${ }^{1}$ Texas A\&M University-Corpus Christi, Harte Research Institute for Gulf of Mexico Studies and \\ Department of Life Sciences, 6300 Ocean Drive, Corpus Christi, Texas 78412-5869, USA \\ ${ }^{2}$ US Geological Survey, Columbia Environmental Research Center, 4200 New Haven Road, Columbia, Missouri 65201, USA
}

\begin{abstract}
Long-term fisheries independent gill net surveys conducted in Texas estuaries from 1975 to 2006 were used to develop spatially explicit estuarine habitat use models for 3 coastal shark species: bull shark Carcharhinus leucas, blacktip shark C. limbatus, and bonnethead shark Sphyrna tiburo. Relationships between environmental predictors and shark distribution were investigated using boosted regression trees (BRT). Bull shark was the most abundant species $(\mathrm{n}=5800)$, followed by blacktip ( $\mathrm{n}=2094$ ), and bonnethead sharks $(\mathrm{n}=1793)$. Environmental conditions influenced distribution patterns of all species and relationships were nonlinear, multivariate, and interactive. Results showed very good model performance and suggested shark distribution is most closely linked to salinity, temperature, and proximity to tidal inlets. By interpolating the BRT models, maps of the probability of capture were produced using ordinary kriging. Results showed that the central region along the Texas coast contains the most important estuarine shark habitat. This area was characterized by warm temperatures, moderate salinities, and abundant tidal inlets. Bull sharks also extended into low salinity estuaries, while blacktip and bonnethead sharks were restricted to areas near tidal passes with moderate salinities. Juvenile sharks were frequently captured, suggesting the Texas coast may constitute important nursery areas for all 3 species. The development of these spatially explicit models allows for prioritization and conservation of areas in a region that has great potential for human disturbance and climate change impacts. These results provide new insight into the habitat requirements of coastal sharks in the northwestern Gulf of Mexico and practical information for managing this resource.
\end{abstract}

KEY WORDS: Shark $\cdot$ Boosted regression trees $\cdot$ Essential fish habitat

Resale or republication not permitted without written consent of the publisher

\section{INTRODUCTION}

Sharks are common inhabitants of coastal seas and may exert strong influences on the structure and function of ecosystems they inhabit (Worm et al. 2005, Carlisle \& Starr 2009, Papastamatiou et al. 2009). Many potential nursery habitats have been degraded by human activity, and disturbances such as climate change may further impair habitat necessary to sustain populations (Lotze et al. 2006). Alteration of habitats is of particular concern for elasmobranchs (Carlisle \& Starr 2009), because essential habitat has not been identified for many species, and environmental conditions that influence habitat selection patterns are not well-understood (Parsons et al. 2005), particularly for young sharks. Many shark species are slow growing and long-lived (Musick et al. 2000), use a variety of habitats over broad spatial scales, and often occur in low densities throughout their range. These life history characteristics typically leave them vulnerable to exploitation, and their relatively large movement ranges in estuarine and coastal waters make identification of essential habitat problematic.

Identification of critical habitat is a well-recognized and essential component of sustainable resource management (Stoner et al. 2001, Stoner 2003). Marine species are often associated with specific physical or biological habitats, and there is growing interest in 
developing spatially explicit habitat maps for management purposes as animal abundance or productivity is directly linked to the amount of suitable areas available (Stoner 2003, Valavanis et al. 2008). Despite this recognition, delineation of essential habitat has been slow for many species in part because necessary data are often unavailable or analytical techniques have been unable to reliably identify critical habitat from available data. Moreover, predicting distributions of large, rare animals based on habitat characteristics can be difficult (Rooper \& Martin 2009). Sampling requires adequate spatial and temporal coverage and must account for a large number of 'zero observations' in the assessment of species such as sharks.

A suite of environmental variables has been hypothesized to influence elasmobranch distributions including temperature (Morrissey \& Gruber 1993, Matern et al. 2000, Ortega et al. 2009), oxygen concentration (Parsons \& Carlson 1998, Heithaus et al. 2009), salinity (Heupel \& Simpfendorfer 2008, Ubeda et al. 2009), and proximity to inlets into estuaries (Grubbs \& Musick 2007). Short-term movement and distributions patterns have been investigated for many shark species using acoustic telemetry or tagging methods and linking distributions to physical or biological patterns at the study sites (Hight \& Lowe 2007, Heupel \& Simpfendorfer 2008, Ortega et al. 2009, Papastamatiou et al. 2009). However, it is difficult to definitively link variations in habitat quality to habitat selection patterns over short time scales (Ortega et al. 2009). Moreover, this may not be evident in short-term studies that do not encompass the full range of environmental conditions that influence large-scale habitat selection patterns (Heupel \& Simpfendorfer 2008). For example, temperature and salinity influence distribution patterns of euryhaline bull sharks that occur over a wide temporal and spatial scale. With increasing rates of disturbance in aquatic habitats (Lotze et al. 2006), improved abilities to predict changes in habitat quality for sensitive species $a$ priori are rapidly needed in order to mitigate habitat loss or population declines. To this end, fish-habitat relationships on larger scales are often investigated by associating environmental conditions with catch records using multivariate statistical techniques (Leathwick et al. 2006, Grubbs \& Musick 2007, Valavanis et. al. 2008).

Coastal habitats in the Gulf of Mexico support a diverse and abundant shark assemblage (Parsons et al. 2005). At least 16 species of coastal sharks use Gulf of Mexico waters off Florida and Texas as juvenile habitat (Hueter \& Tyminski 2007, McCandless et al. 2007). However, coastal shark distribution patterns in the northwestern Gulf of Mexico including the entire Texas coast are poorly understood, and there is currently no appropriate baseline with which to measure future management actions or predict the impact of natural or anthropogenic disturbances. The goal of this study was to develop species distribution models for 3 coastal shark species in the northwestern Gulf of Mexico to promote sustainable management of these important predators. We developed a long-term fisheriesindependent data set to link shark distribution and environmental conditions and develop species-specific distribution models. Specifically, the goal of this study was to characterize environmental influences on shark distribution patterns of the northern Gulf of Mexico.

\section{MATERIALS AND METHODS}

Study Area. This study was conducted in 9 major bay systems along the Texas coast in the northwestern Gulf of Mexico from 1975 to 2006 (Fig. 1). Barrier islands separate coastal estuaries from the Gulf of Mexico along the majority of the coast and saltwater exchange occurs via 6 major tidal inlets. Texas bays are shallow, subtropical estuaries that are physically dynamic, support a variety of habitat types, and provide nursery habitat for many nektonic species of recreational, commercial, or ecological importance (Reese et al. 2008).

Field Collections. Biological: Shark catch data were obtained from the Texas Parks and Wildlife

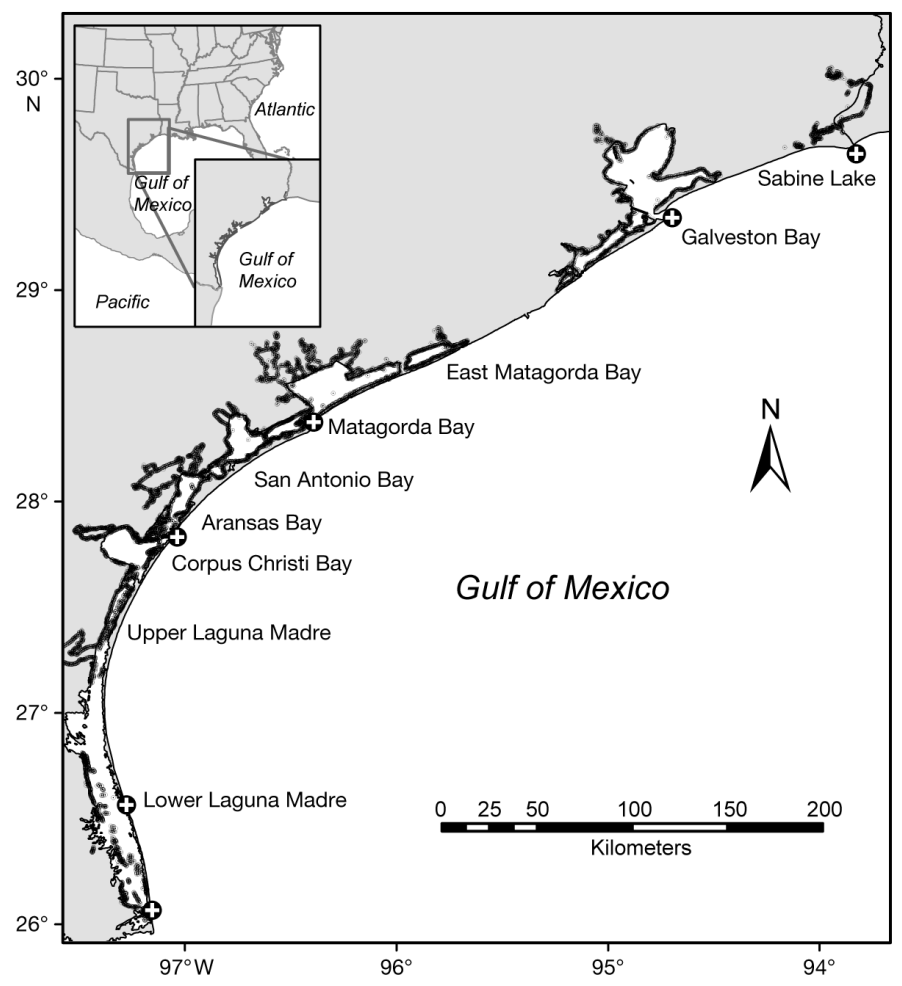

Fig. 1. Coastal shark gill net survey locations $(n=19757)$ from 1975 to 2006 in Texas, USA. Estuaries are connected to the Gulf of Mexico via 6 ocean passes (tidal inlets, $\boldsymbol{\oplus}$ ), from north to south: Sabine Pass, Galveston Pass, Matagorda ship channel, Aransas Pass, Mansfield Pass, and Brazos Santiago Pass 
Department coastwide fisheries gill net monitoring program that was established in all Texas bay systems in 1975 and continued through 2006. Coastal fisheries resource monitoring data were collected as a stratified cluster sampling design; each bay system serves as non-overlapping strata with a fixed number of samples per season $\left(\mathrm{n}=45\right.$ bay $^{-1}$ season $\left.^{-1}\right)$. Gill nets were deployed each spring (April to June) and fall (September to November) (Martinez-Andrade et al. 2009). Sample locations were drawn independently and without replacement for each season (MartinezAndrade et al. 2009). For this study, gill net collection data from 9 bay systems (1975 to 2006, n = 19757; Table 1) were used to identify shark-habitat relationships and develop shark distribution maps within Texas' major bay systems. Sharks were sampled using standardized gill nets (183 $\mathrm{m}$ in length) set perpendicular to shore. Nets were constructed of 4 panels with mesh sizes of $76,102,127$, and $152 \mathrm{~mm}$, in this order with the smallest mesh size nearest the shore. Gill nets were deployed $1 \mathrm{~h}$ before sunset, fished overnight, and retrieved within $4 \mathrm{~h}$ off sunrise the following day (set time was noted for each sample). Captured sharks were identified to species, measured, and released. Gill nets employed in this study were inefficient at capturing sharks $>2 \mathrm{~m}$; thus, large sharks were rare in this study although they are present in the bay at times (M. Fisher pers. comm.).

Physical: Patterns of 11 variables relevant to sharks were examined coastwide to investigate relationships between environmental conditions and shark distributions (Table 1). Data including salinity, temperature, turbidity, and dissolved oxygen (DO) were collected in the surface waters $(0$ to $15 \mathrm{~cm})$ at the offshore end of the gill net during net retrieval (Martinez-Andrade et al. 2009). Turbidity readings were processed in the laboratory within $24 \mathrm{~h}$ using a calibrated turbidimeter. Depth at the offshore end of each gill net set was also noted. All variables were measured during each sampling (i.e. all years and bays) although a few observa- tions $(<1 \%)$ had missing values for a single variable. Observations missing only a single variable were retained for the analysis as the modeling technique accommodates missing values through the use of surrogates (Elith et al. 2008).

Freshwater inflow into the major estuarine systems was determined from US Geological Survey (USGS) (1976 to 2006; no missing years) stream gauges (available at: http://midgewater.twdb.state.tx.us/bays_ estuaries/hydrologypage.html) to estimate the relative importance of freshwater inflow on shark habitat quality. Mean monthly surface inflow and freshwater balance were determined for each bay system (except East Matagorda Bay, data unavailable) during the study using the following equations provided by the Texas Water Development Board, Austin, Texas (available at: http://midgewater.twdb.state.tx.us/bays_estuaries/hydrologypage.html):

(1) Surface inflow $=$ Gauged flow + Modeled flow Diverted flow + Returned flow

(2) Freshwater balance $=$ Surface inflow - Evaporation from estuary surface + Precipitation on estuary surface.

Spatial: Saltwater exchange between bays and the Gulf of Mexico occurs via 6 tidal inlets (Fig. 1). To examine potential relationships between estuarine shark distribution and the connection to the Gulf of Mexico, we calculated the distance from each sampling location to the nearest tidal connection to the Gulf of Mexico using the cost-distance function in the ArcGIS software package with the spatial analyst extension (ESRI), using the shoreline as a barrier (Whaley et al. 2007). Cost-distance functions calculate the shortest distance between 2 points but were constrained within geographic boundaries (e.g. water) to provide more accurate relative distance estimates than euclidian (straight-line) techniques.

Modeling approach. We used boosted regression trees (BRT) to examine relationships between shark distribution and environmental variables and to pre-

Table 1. Predictors used in the analyses. na: not applicable

\begin{tabular}{|c|c|c|c|}
\hline Variable & Description & Mean & Range \\
\hline Salinity (psu) & Surface salinity at offshore end of the gill net & 22.8 & $0-69$ \\
\hline Temperature $\left({ }^{\circ} \mathrm{C}\right)$ & Surface temperature at offshore end of gill net & 26.2 & $4.8-38.0$ \\
\hline Depth (m) & Depth at the offshore end of gill net set & 1.1 & $0.1-8.5$ \\
\hline Distance (cost-distance units) & Distance to nearest tidal inlet & 12.6 & $1-32$ \\
\hline Turbidity (NTU) & Turbidity of surface water at offshore end of gill net & 28.2 & $0-999$ \\
\hline $\mathrm{DO}\left(\mathrm{mg} \mathrm{O}_{2} \mathrm{l}^{-1}\right)$ & $\begin{array}{l}\text { Surface dissolved oxygen concentration at offshore } \\
\text { end of gill net }\end{array}$ & 7.9 & $0.6-28.5$ \\
\hline Surface inflow (acre-feet $\mathrm{mo}^{-1}$ ) & Mean monthly surface inflow per bay system & 398594 & $24-4355617$ \\
\hline Freshwater balance (acre-feet $\mathrm{mo}^{-1}$ ) & $\begin{array}{l}\text { Calculated from surface inflow - evaporation from } \\
\text { estuary surface }\end{array}$ & 369569 & $-269000-4370924$ \\
\hline Time $(\mathrm{h})$ & Number of hours gill net was deployed & 13.7 & $9.4-21.1$ \\
\hline Month & Month sample occurred & na & na \\
\hline Year & Year sample occurred & na & na \\
\hline
\end{tabular}


dict probability of capture at sites withheld from the model building for bull, blacktip, and bonnethead sharks. Prior to model fitting the entire data set was randomly partitioned into training and testing data sets ( $\mathrm{n}=9879$ training; $\mathrm{n}=9878$ testing). After model fitting, probability of capture was predicted to 9878 testing samples covering the entire coast. Coastwide species distribution models were then developed by interpolating catch probabilities from the 9878 independent samples using ordinary kriging. Suites of environmental conditions were determined for 'spring' and 'fall' conditions based on environmental parameters measured during each season of this study (samples were not collected during winter). The BRT model output was then used to predict probability of capture coastwide during these specific seasonal conditions (Fig. 2).

Boosted regression trees: The BRT use a modelaveraging (ensemble) method that allows for both explanation and prediction (Elith et al. 2008). Despite this utility BRT have only recently been applied to ecological questions (Friedman 2001, Leathwick et al. 2006, Elith et al. 2008). Each individual model consists of a simple regression tree based on a series of binary splits constructed from the predictor variables (Hastie et al. 2001), accommodates continuous or categorical predictors, missing values, and is not affected by transformation or outliers. This technique can also fit complex

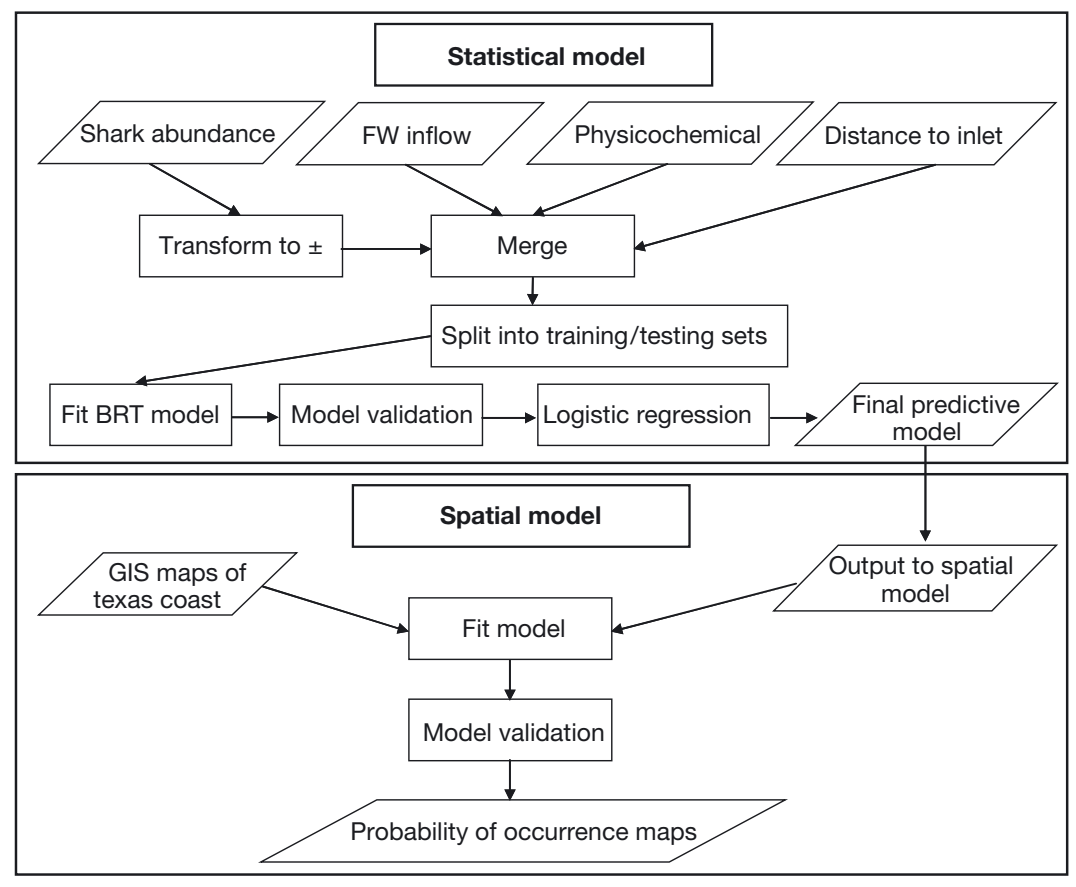

Fig. 2. Carcharhinus leucas, C. limbatus and Sphyrna tiburo. Modeling and spatial distribution of bull, blacktip, and bonnethead sharks on the Texas coast. Rectangles indicate a process and parallelograms indicate a data input or output. BRT = Boosted regression trees, GIS = Geographic information system. FW: freshwater non-linear relationships and often has superior predictive performance to other techniques such as generalized linear and additive models that are often used to model species-habitat relationships (Elith et al. 2006, Leathwick et al. 2006, Elith et al. 2008, Leathwick et al. 2008, Parisien \& Moritz 2009). The relative importance of variables can be determined by averaging the number of times a variable is selected for splitting and the squared improvement resulting from these splits (Friedman 2001, Friedman \& Meulman 2003). Values are scaled to 100, and higher numbers indicate a stronger influence on the response variable. The ability to model interactions is controlled by a tree complexity (tc) parameter where the value specifies the number of nodes on each tree and subsequently the ability to model interactions (Leathwick et al. 2006).

Analyses were carried out in R (version 2.7.1, R Development Core Team, 2004) using the 'gbm' library supplemented with functions from Sing et al. (2005) and Elith et al. (2008). All models were fit to allow interactions using a tree complexity of 5 with a learning rate 0.01 or 0.005 to minimize predictive deviance and maximize predictive performance. During preliminary analyses, a range of tree complexities and learning rates were examined. Complex trees (i.e. $t c=5$ ) improved predictive performance and learning rates (lr) $>0.05$ over-fit training data, while rates slower than 0.005 did not improve model performance. Ten-fold cross validation of training data $(\mathrm{n}=9879)$ was used to determine the optimal number of trees for each model (i.e. number of trees giving best predictive performance) and ranged between 2400 and 3750 trees.

Despite careful model fitting, BRT models typically over-fit training data sets (Elith et al. 2008, Leathwick et al. 2008); therefore, model performance was assessed on predictions to the independent testing set $(n=9878)$ that were withheld during cross validation. For each model, 2 performance metrics were determined: (1) predictive deviance and (2) the area under the receiver operator characteristic curve (ROC). Predictive deviance provides an estimate of the fit between predicted and raw values when predicting to independent data and was reported as a percentage of the total deviance for each model. Values for ROC estimate the degree to which fitted values discriminate between observed presences and absences and can be interpreted as the probability that a presence for a species drawn at random will have a 
higher fitted probability than an absence drawn at random (Parisien \& Moritz 2009). Values of ROC range from 0.5 to 1 where a 1 indicates perfect discrimination of probabilities between presence and absence samples and a value of 0.5 indicates that model performance is no better than random. While models with ROC values $>0.6$ are considered useful (Parisien \& Moritz 2009), values $>0.8$ are considered very good, and above $>0.9$ excellent (Lane et al. 2009). In addition to identifying important environmental variables contributing to shark distribution patterns, we also wanted to generate spatially explicit predictions of catch probability at locations withheld during model training. We predicted the probability of capture to each site in the testing data set $(\mathrm{n}=9878)$ using a form of logistic regression (Elith et al. 2008) where the probability that a species occurs $(y=1)$, at a location with covariates $X$, $P(y=1 \mid X)$ using the logit: $\operatorname{logit}(P(y=1 \mid X)=f(X))$.

Habitat suitability models: Kriging is a spatial interpolation algorithm that was used to predict values at unsampled sites in the study area (Saveliev et al. 2007). This method uses the variogram to express the spatial variation, and it minimizes the error of predicted values, which are estimated by spatial distribution of the predicted values. We used ordinary kriging with a spherical semivariogram with the predicted probabilities of capture at each location (from the BRT model) as input into the kriging model. As this technique assumes normality, probability of capture values was transformed prior to analysis using the natural logarithm (ln) and met this assumption. To evaluate seasonal differences in distribution patterns, environmental conditions during spring and fall seasons were determined coastwide from the sampling data using ordinary kriging. Therefore, environmental conditions for spring and fall were determined for the entire study area and the BRT model was used to predict probability of capture during these conditions. Predictive performance of the spatial models were validated using cross-validation. As samples were collected nearshore, spatial models were constrained within $1 \mathrm{~km}$ of the shoreline (Whaley et al. 2007).

\section{RESULTS}

\section{Physicochemical}

Patterns of 11 predictor variables were examined to investigate relationships between environmental conditions and shark distributions (Table 1). On the Texas coast, physical conditions vary widely among bay systems creating an ideal study region. Salinity increases with decreasing latitude from hyposaline (positive) (Sabine Lake and Galveston Bay) to moderately saline (15 to $35 \mathrm{psu}$ ) along the central coast, and hypersaline (negative) estuaries (>35 psu) in the southernmost Upper and Lower Laguna Madre (Fig. 3A). Mean sea

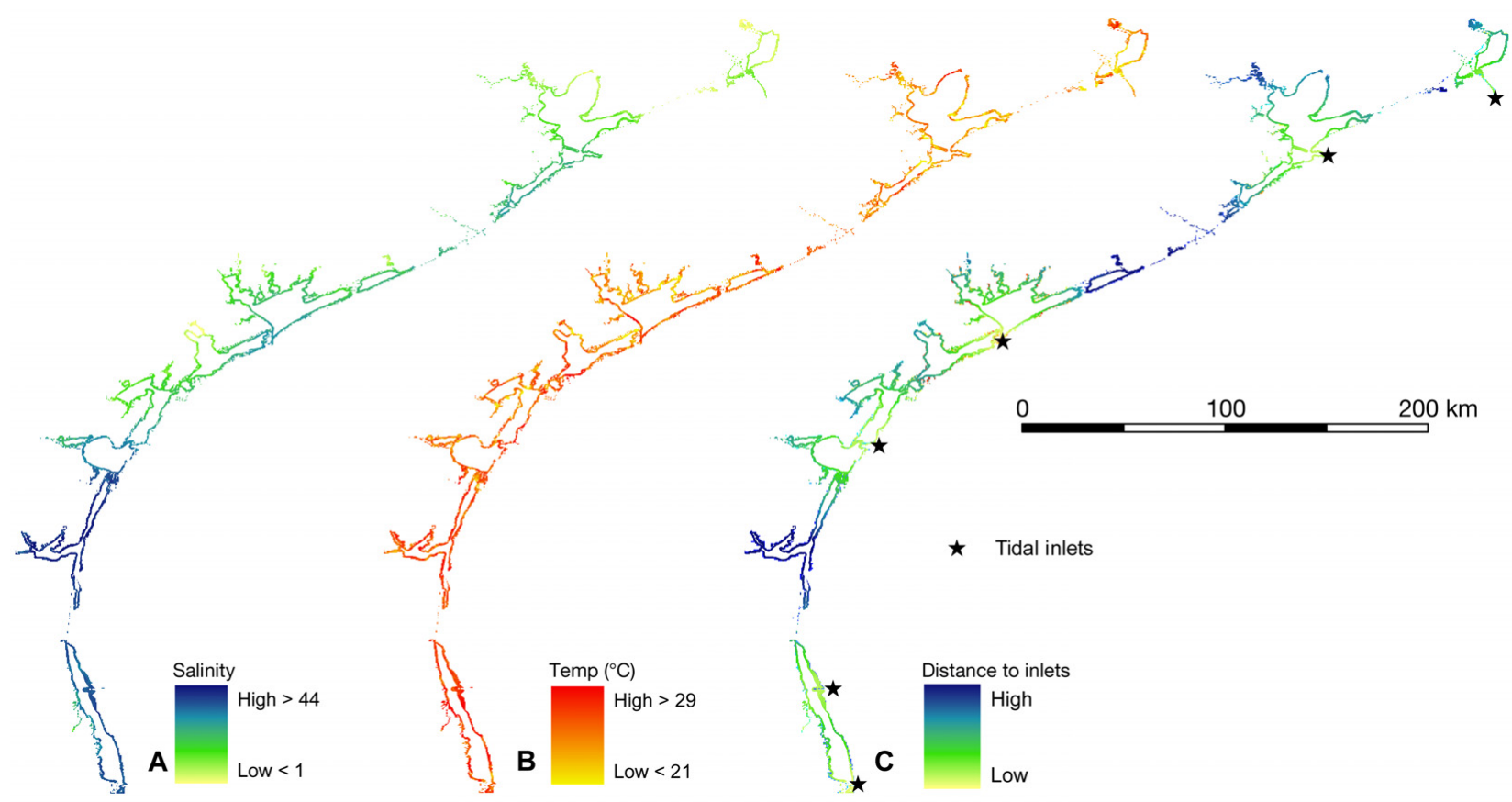

Fig. 3. (A) Mean salinity (0 to $44 \mathrm{psu}$ ), (B) temperature $\left(21\right.$ to $\left.29^{\circ} \mathrm{C}\right)$, and (C) distance to tidal inlets (cost-distance units) of sample locations in Texas bays. Distance to tidal inlet was estimated using the cost-distance function in ArcGIS. Maps of mean salinity and temperature were created by kriging measured values $(n=17757)$ during gill net sampling from 1976 to 2006 
Table 2. Summary of physicochemical predictors used in the analysis. DO: dissolved oxygen

\begin{tabular}{|lccccc|}
\hline Location & Salinity $(\mathrm{psu})$ & Temperature $\left({ }^{\circ} \mathrm{C}\right)$ & Depth $(\mathrm{m})$ & Turbidity $(\mathrm{NTU})$ & DO $\left(\mathrm{mg} \mathrm{O}_{2} \mathrm{l}^{-1}\right)$ \\
\hline Sabine Lake & $7.9 \pm 6.1$ & $25.6 \pm 4.1$ & $1.1 \pm 0.5$ & $19.6 \pm 28.5$ & $7.7 \pm 1.6$ \\
Galveston Bay & $16.9 \pm 8.5$ & $25.5 \pm 3.9$ & $1.2 \pm 0.5$ & $27.5 \pm 31.0$ & $7.9 \pm 2.0$ \\
East Matagorda Bay & $20.8 \pm 8.3$ & $26.2 \pm 4.2$ & $0.9 \pm 0.3$ & $33.4 \pm 39.9$ & $7.8 \pm 1.9$ \\
Matagorda Bay & $19.3 \pm 9.0$ & $25.8 \pm 3.9$ & $1.1 \pm 0.4$ & $36.9 \pm 47.7$ & $7.7 \pm 1.7$ \\
San Antonio Bay & $18.7 \pm 10.8$ & $26.1 \pm 3.7$ & $1.1 \pm 0.4$ & $25.4 \pm 33.2$ & $8.1 \pm 2.0$ \\
Aransas Bay & $18.3 \pm 9.4$ & $26.2 \pm 3.7$ & $1.1 \pm 0.4$ & $27.1 \pm 33.6$ & $8.4 \pm 2.1$ \\
Corpus Christi Bay & $29.0 \pm 7.4$ & $26.2 \pm 3.7$ & $1.3 \pm 0.6$ & $24.1 \pm 33.4$ & $7.7 \pm 1.8$ \\
Upper Laguna Madre & $37.5 \pm 10.1$ & $26.8 \pm 3.7$ & $1.1 \pm 0.4$ & $27.6 \pm 44.7$ & $7.5 \pm 1.9$ \\
Lower Laguna Madre & $32.2 \pm 7.3$ & $27.1 \pm 3.5$ & $1.0 \pm 0.5$ & $33.4 \pm 56.9$ & $7.9 \pm 2.1$ \\
\hline
\end{tabular}

surface temperature also increases slightly from north to south along the coast (Fig. 3B). Distance to the nearest inlet varies for the 9 major bay systems with the Upper Laguna Madre and East Matagorda Bay the most isolated from the GOM (Fig. 3C). DO concentration, turbidity, and sampling depths were similar among bay systems and a complete description of the environmental variables and ranges are described in Table 2. Freshwater inflow and balance, which affect salinity, varied dramatically along the coast with highest inflow rates in the northern bays (Sabine Lake and Galveston Bay), intermediate along the central coast and, low in the Laguna Madre (Table 2).

\section{Shark distribution and habitat modeling}

The shark assemblage in this study was numerically dominated by 3 species, bull shark, blacktip, and bonnethead shark, and a total of 9687 sharks were captured in the study. Size-frequency histograms were developed for each species and suggest that blacktip and bull shark catch was dominated by juveniles, while bonnethead were collected throughout their ontogeny (Fig. 4). With the exception of bull sharks, length distributions were bimodal, suggesting that multiple age classes are using coastal bays.

\section{Bull shark}

Bull shark was the most abundant species sampled (frequency of occurrence $=12.0 \%$ ), and model evaluation suggested very good predictive performance to independent data $(\mathrm{ROC}=0.84$; Table 3 ). Bull shark distributions were most strongly influenced by salinity and temperature (Fig. 5). Fitted functions from the BRT model indicate that bull sharks occur in salinities from 0 to 40 psu but were most common in moderate salinities (15 to $30 \mathrm{psu}$ ) and rarely occurred in areas >35 psu (Fig. 6A). With respect to temperature, bull sharks were rare in waters below $20^{\circ} \mathrm{C}$, while probability of capture
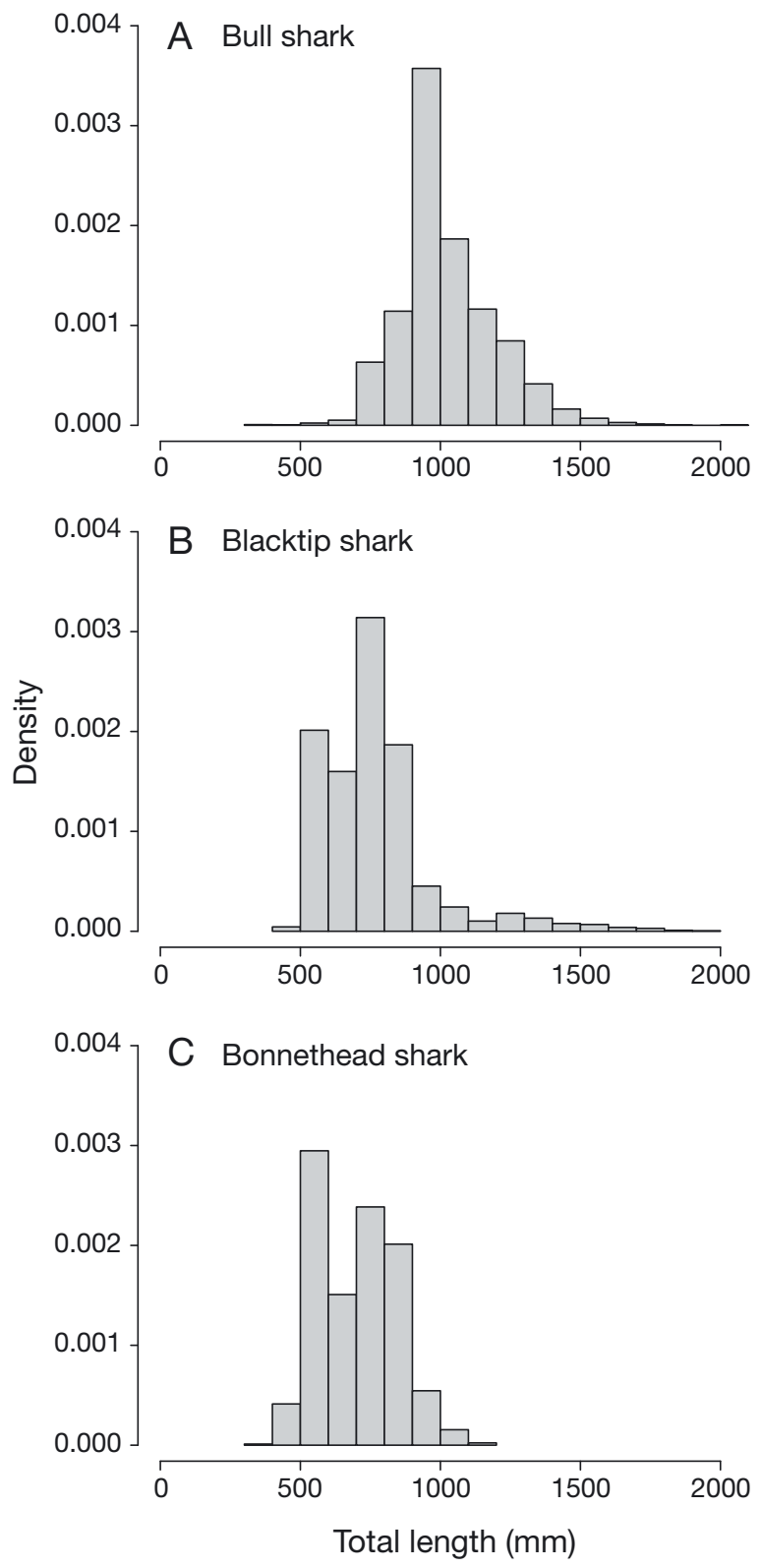

Fig. 4. Carcharhinus leucas, C. limbatus and Sphyrna tiburo. Size frequency and probability density histogram of (A) bull shark, (B) blacktip shark, and (C) bonnethead shark 
Table 3. Predictive performance of boosted regression trees (BRT) models evaluated on 3 data sets, training ( $\mathrm{n}=9879)$, cross-validation $(\mathrm{n}=9879)$, and independent $(\mathrm{n}=9878)$ for 3 coastal shark species. $\mathrm{lr}=$ learning rate, $\mathrm{nt}=$ number of trees fitted

\begin{tabular}{|c|c|c|c|c|c|c|c|c|c|c|}
\hline \multirow[b]{2}{*}{ Species } & \multirow[b]{2}{*}{ lr } & \multirow[b]{2}{*}{ nt } & \multicolumn{3}{|c|}{ Percentage deviance explained } & \multirow[b]{2}{*}{$\begin{array}{c}\text { Total } \\
\text { deviance }\end{array}$} & \multicolumn{3}{|c|}{$\begin{array}{l}\text { Area under the receiver operating } \\
\text { characteristic curve (ROC) }\end{array}$} & \multirow[b]{2}{*}{$\begin{array}{r}\text { Frequency of } \\
\text { occurrence }(\%\end{array}$} \\
\hline & & & $\begin{array}{c}\text { Inde- } \\
\text { pendent }\end{array}$ & $\begin{array}{c}\text { Cross- } \\
\text { validation }\end{array}$ & Training & & $\begin{array}{l}\text { Inde- } \\
\text { pendent }\end{array}$ & $\begin{array}{c}\text { Cross- } \\
\text { validation (SE) }\end{array}$ & Training & \\
\hline Bull shark & 0.01 & 3500 & 24.30 & 20.30 & 40.00 & 0.752 & 0.84 & $0.823(0.005)$ & 0.928 & 12 \\
\hline Blacktip shark & 0.005 & 3750 & 18.60 & 18.30 & 45.70 & 0.308 & 0.87 & $0.848(0.006)$ & 0.962 & 3 \\
\hline Bonnethead shark & 0.005 & 2400 & 18.60 & 18.30 & 45.70 & 0.277 & 0.86 & $0.881(0.009)$ & 0.963 & 3 \\
\hline
\end{tabular}

increased rapidly with temperatures up to $33^{\circ} \mathrm{C}$ and then declined precipitously. However, other variables including freshwater inflow, turbidity, and proximity to tidal inlets also influenced distribution patterns (Fig. 5).

Spatially explicit model predictions of probability of capture from the BRT models were determined for spring, fall, and mean overall conditions. Ordinary kriging was used for spatial interpolation of probability of catch values from the study sites to nearby unsampled areas. Kriging models were validated using crossvalidation and had very low error rates (Table 4). The

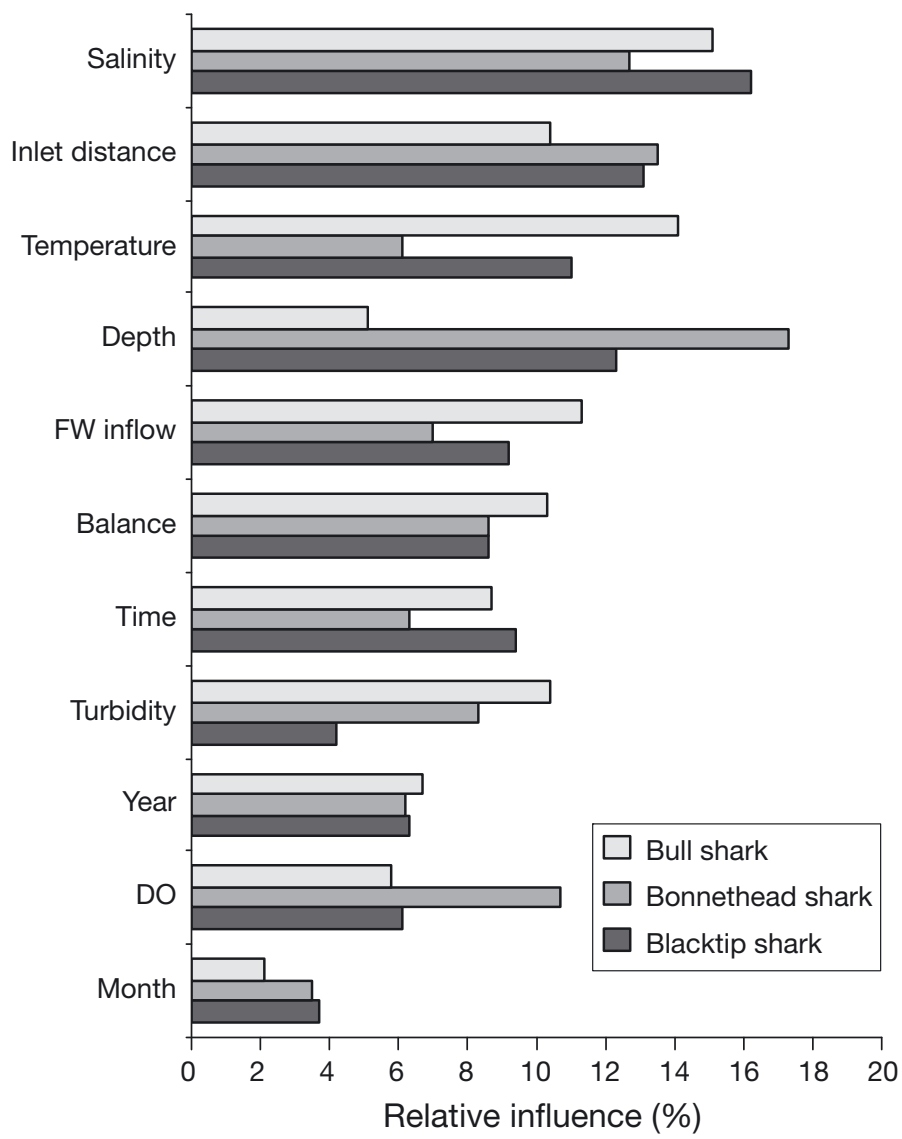

Fig. 5. Average contributions (\%) of environmental variables predicting presence or absence of 3 coastal shark species. Variables are ranked in decreasing order based on average overall contribution. DO: dissolved oxygen. FW: freshwater highest probability of capturing bull sharks occurred along the central coast in Matagorda and San Antonio bays (Fig. 7). Moderate catch rates were predicted along most of the coast including the hyposaline Galveston Bay and Sabine Lake. Low probabilities of capture were predicted in East Matagorda and Upper and Lower Laguna Madre due to combination of shallow waters and high salinities (Upper and Lower Laguna Madre). Few seasonal differences were noted between spring and fall probability of capture estimates and was supported by the relatively low importance of the month variable in the BRT model (Fig. 5).

\section{Blacktip shark}

Blacktip sharks were the second most abundant species sampled (frequency of occurrence $=3.4 \%$ ), and model evaluation suggested good predictive performance to independent data (ROC $=0.87$; Table 3$)$. Similar to bull shark, fitted functions of the most influential predictors were non-linear and complex (Fig. 6B). Fitted functions were most strongly influenced by salinity, inlet distance, depth, and temperature suggesting a preference for warm waters near tidal inlets of moderate salinities that are proximate to deeper waters.

Spatial predictions of catch probabilities from the BRT models were made using ordinary kriging and had low error rates (Table 4). For blacktip sharks, highest probability of capture was predicted along the central coast in Matagorda and San Antonio bays (Fig. 8) and predicted distribution patterns were very similar between seasons. High probability areas were restricted near tidal inlets along the coast. Probability of capture was very low in all areas of the Sabine Lake (hyposaline) and the Upper Laguna Madre (hypersaline).

\section{Bonnethead shark}

Bonnethead sharks were captured in $3.1 \%$ of all samples. Model evaluation for this species also suggested good predictive performance of the BRT to independent data $(\mathrm{ROC}=0.86$; Table 3 ). Similar to blacktip 
sharks, fitted functions for bonnethead were highest at sites $>1 \mathrm{~m}$ depth and proximal to tidal inlets (Fig. 6C). Salinity also influenced distribution patterns, as bonnethead demonstrated a distinct preference for salinities between 20 and 40 psu.

Spatial predictions of catch probabilities from the BRT models were made for bonnethead shark using ordinary kriging and had low error rates (Table 4). Probability of capture of bonnethead was similar to blacktip sharks in that areas near tidal inlets with access to deeper waters were most important. Highest probabilities of capture were predicted near the inlets on the central coast and this was consistent between seasons, and for overall estimates (Fig. 9). Probability of capture was low in both northern bay systems
(Galveston Bay and Sabine Lake), however was higher in Lower Laguna Madre than for both bull and blacktip sharks.

\section{DISCUSSION}

Distribution patterns of sharks were influenced by several environmental variables. Overall, both general and species-specific patterns were observed. All 3 species displayed distinct salinity preferences, and this was the most important factor in the BRT model for blacktip and bull sharks, and the third most influential variable for bonnethead. These species were most common in moderate salinities (bull shark 10 to $30 \mathrm{psu}$,
A
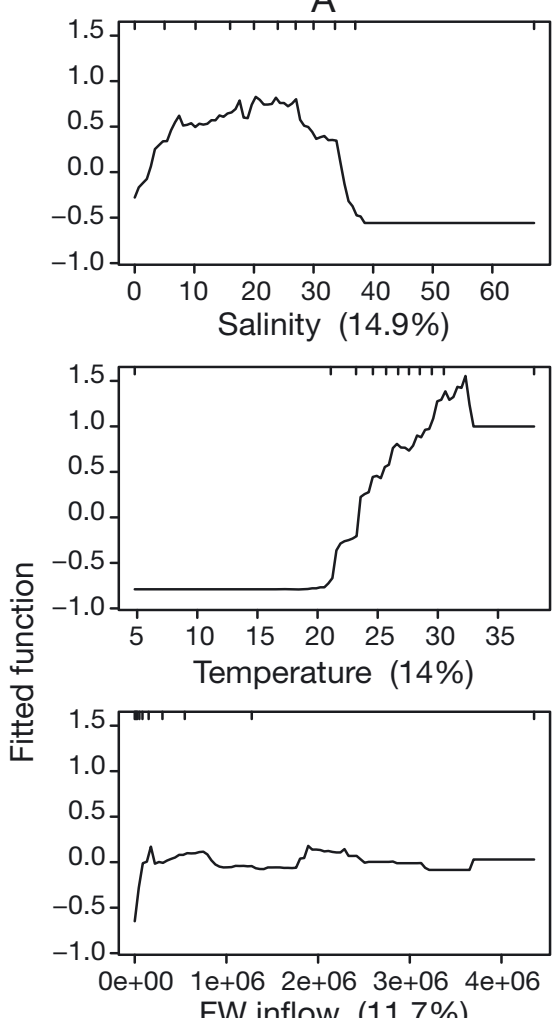

FW inflow (11.7\%)

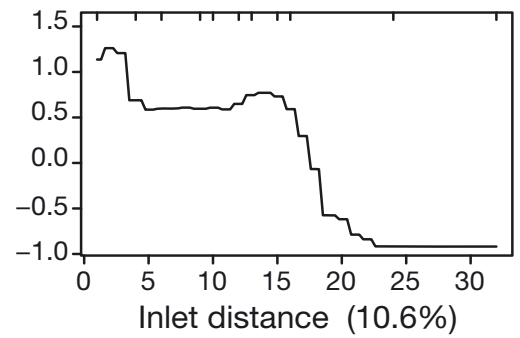

B
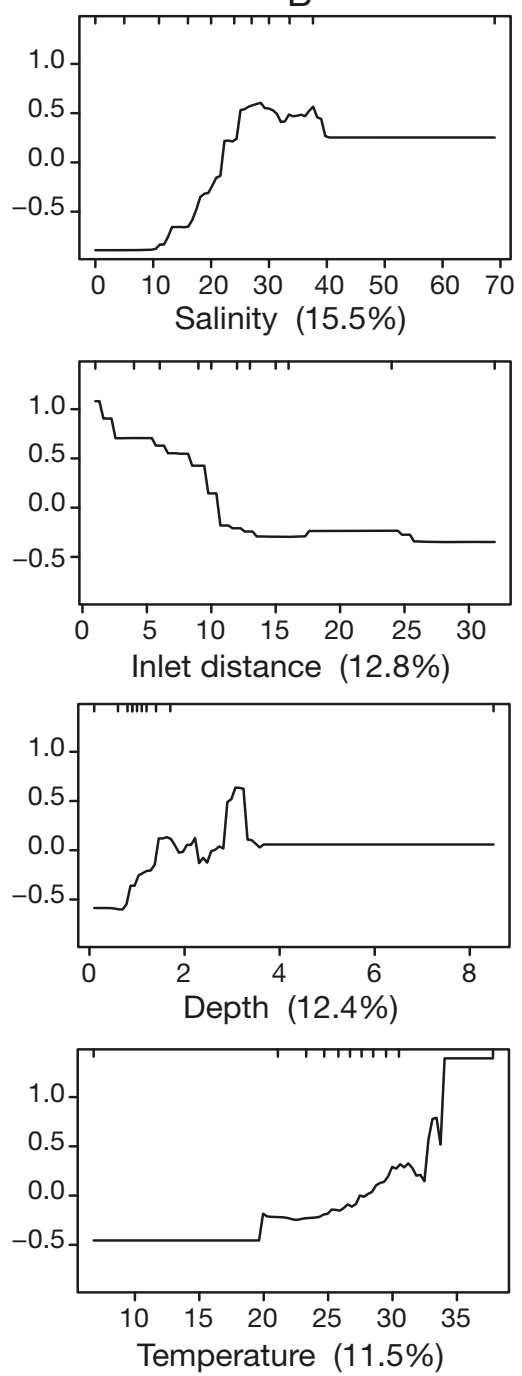
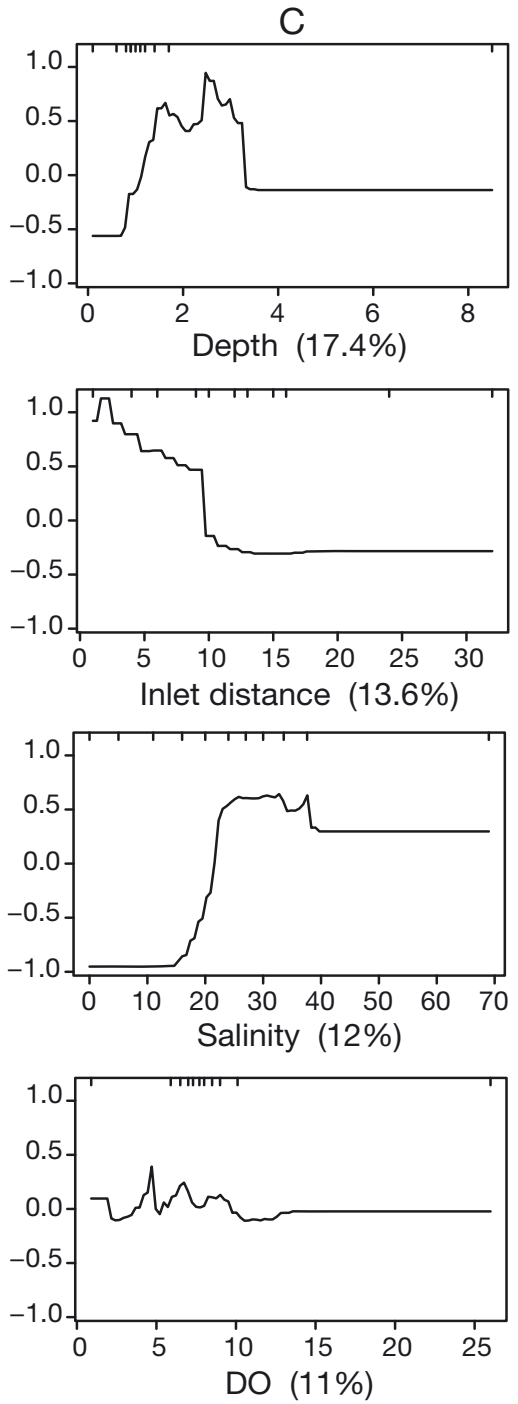

Fig. 6. Carcharhinus leucas. C. limbatus. Sphyrna tiburo. Functions fitted for the 4 most important predictor variables by a boosted regression trees (BRT) model relating the probability of occurrence of sharks to the environment for (A) bull shark, (B) blacktip shark, and (C) bonnethead shark. $Y$-axes are on the logit scale with mean zero. $X$-axes parameters: salinity (psu), temperature $\left({ }^{\circ} \mathrm{C}\right)$, freshwater $(\mathrm{FW})$ inflow $\left(\right.$ acre-feet $\left.\mathrm{mo}^{-1}\right)$, inlet distance (cost-distance units), depth (m), dissolved oxygen (DO; $\mathrm{mg} \mathrm{O}_{2} \mathrm{l}^{-1}$ ) 
Table 4. Cross-validation results of ordinary kriging model for 3 coastal shark species. Mean cond.: mean overall conditions

\begin{tabular}{|c|c|c|c|c|c|c|c|c|c|}
\hline & \multicolumn{3}{|c|}{ Bull shark } & \multicolumn{3}{|c|}{ Blacktip shark } & \multicolumn{3}{|c|}{ Bonnethead shark } \\
\hline & Spring & Fall & $\begin{array}{l}\text { Mean } \\
\text { cond. }\end{array}$ & Spring & Fall & $\begin{array}{l}\text { Mean } \\
\text { cond. }\end{array}$ & Spring & Fall & $\begin{array}{l}\text { Mean } \\
\text { cond. }\end{array}$ \\
\hline Mean & $<0.01$ & $<0.01$ & $<0.01$ & $<0.01$ & $<0.01$ & $<0.01$ & $<0.01$ & $<0.01$ & 0.01 \\
\hline Root-mean-square & 0.07 & 0.12 & 0.12 & 0.03 & 0.05 & 0.05 & 0.00 & 0.05 & 0.05 \\
\hline Average SE & 0.07 & 0.12 & 0.40 & 0.03 & 0.06 & 0.06 & 0.04 & 0.05 & 0.11 \\
\hline Mean standardized & 0.00 & 0.00 & -0.01 & 0.00 & 0.00 & 0.00 & 0.04 & 0.00 & 0.12 \\
\hline Root-mean-square standardized & 0.98 & 1.00 & 0.37 & 0.92 & 0.90 & 0.83 & 0.00 & 0.96 & 0.53 \\
\hline $\mathrm{n}$ & 7704 & 8032 & 7856 & 7704 & 8032 & 7856 & 8312 & 8032 & 7856 \\
\hline
\end{tabular}

blacktip shark 20 to 35 psu, bonnethead shark 20 to 40 psu) and avoided hypersaline waters (i.e. Upper Laguna Madre). Capture rates of blacktip and bonnethead sharks were low in hyposaline waters, while bull sharks were common in these areas. Bull sharks are unique in their ability to osmoregulate long-term in low salinity waters. Thorson et al. (1973) hypothesized that salinity would not influence coastal bull shark distribution patterns. However our data, as well as other recent studies (Simpfendorfer et al. 2005, Heupel and Simpfendorfer 2008), indicate that bull shark captures occurred within a distinct range of moderate salinities. However, blacktip sharks were uncommon in low salinities and were largely restricted to areas between salinities 20 to $35 \mathrm{psu}$. This preference is similar to results from Florida, USA estuaries were blacktip sharks were found between 20 to 36 psu; however, juveniles were restricted to a much narrower range (31 to $36 \mathrm{psu}$; Bethea et al. 2006). Movement of bonnethead sharks in a Florida, USA estuary was also influ- enced by salinity and were found at salinities between 11 to 36 psu over a 2 year period (Ubeda et al. 2009), similar to the results of the present long-term study.

Distribution patterns of sharks in relation to salinity may be a mechanism to reduce energetic costs associated with osmoregulation permitting increased growth rates and reducing times in size classes where mortality rates are highest. Avoidance of hypersaline areas such as Upper Laguna Madre may reflect their inability or physiological costs of osmoregulation under extreme hypersaline conditions. Based on length-atage estimations, the majority of sharks captured in the present study were juveniles (except bonnethead sharks) and evidence suggests that energetic costs of osmoregulation are highest for young sharks when surface to volume ratio is lowest (Heupel \& Simpfendorfer 2008). Juvenile blacktip sharks were captured in a narrow range of salinities in Florida, USA (31 to $36 \mathrm{psu}$ ), while adults occurred in a much broader range

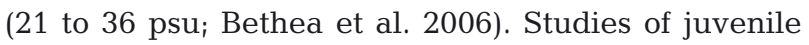

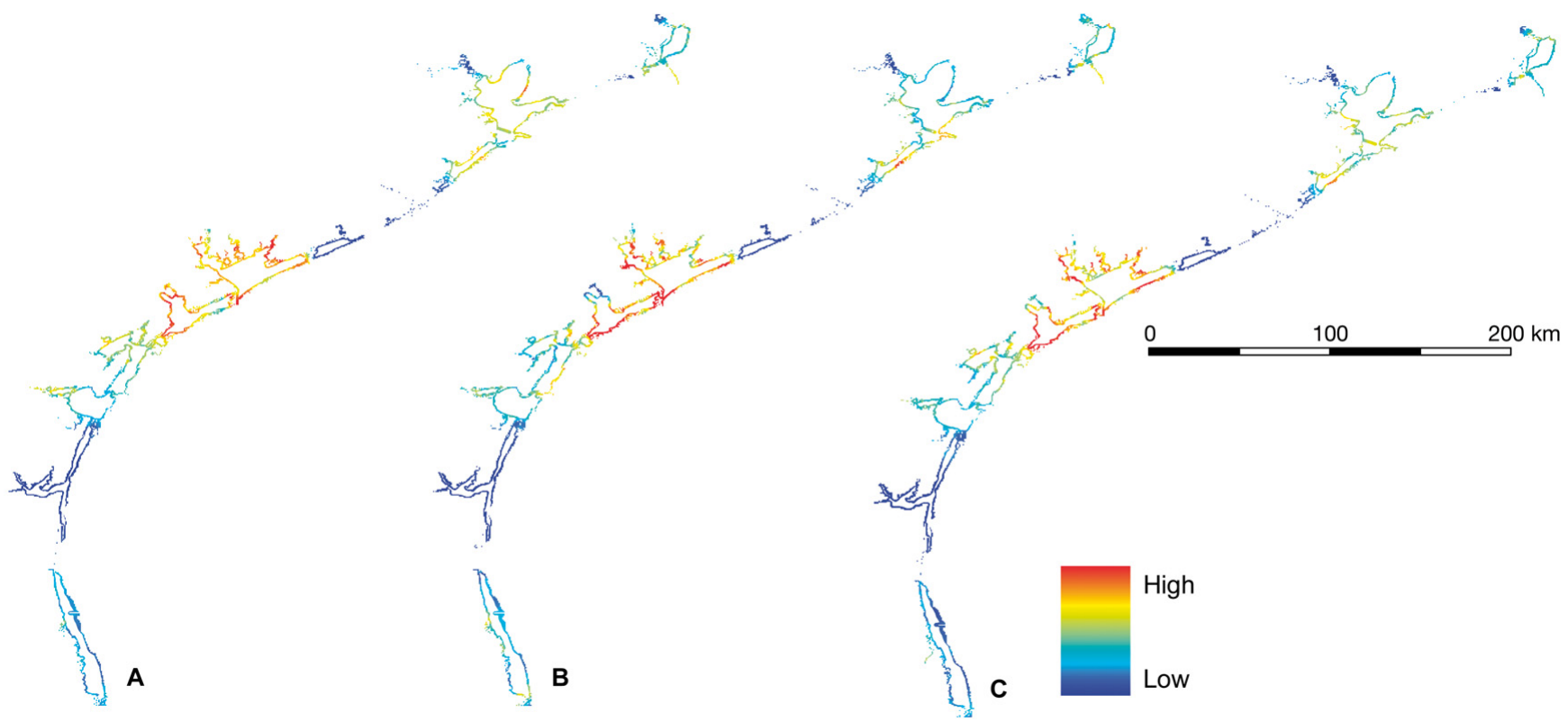

Fig. 7. Carcharhinus leucas. Probability of capture maps of bull shark along the Texas coast as predicted by a boosted regression trees model for (A) spring, (B) fall, and (C) mean overall conditions. Predictions were restricted to areas within $1 \mathrm{~km}$ of the shoreline 


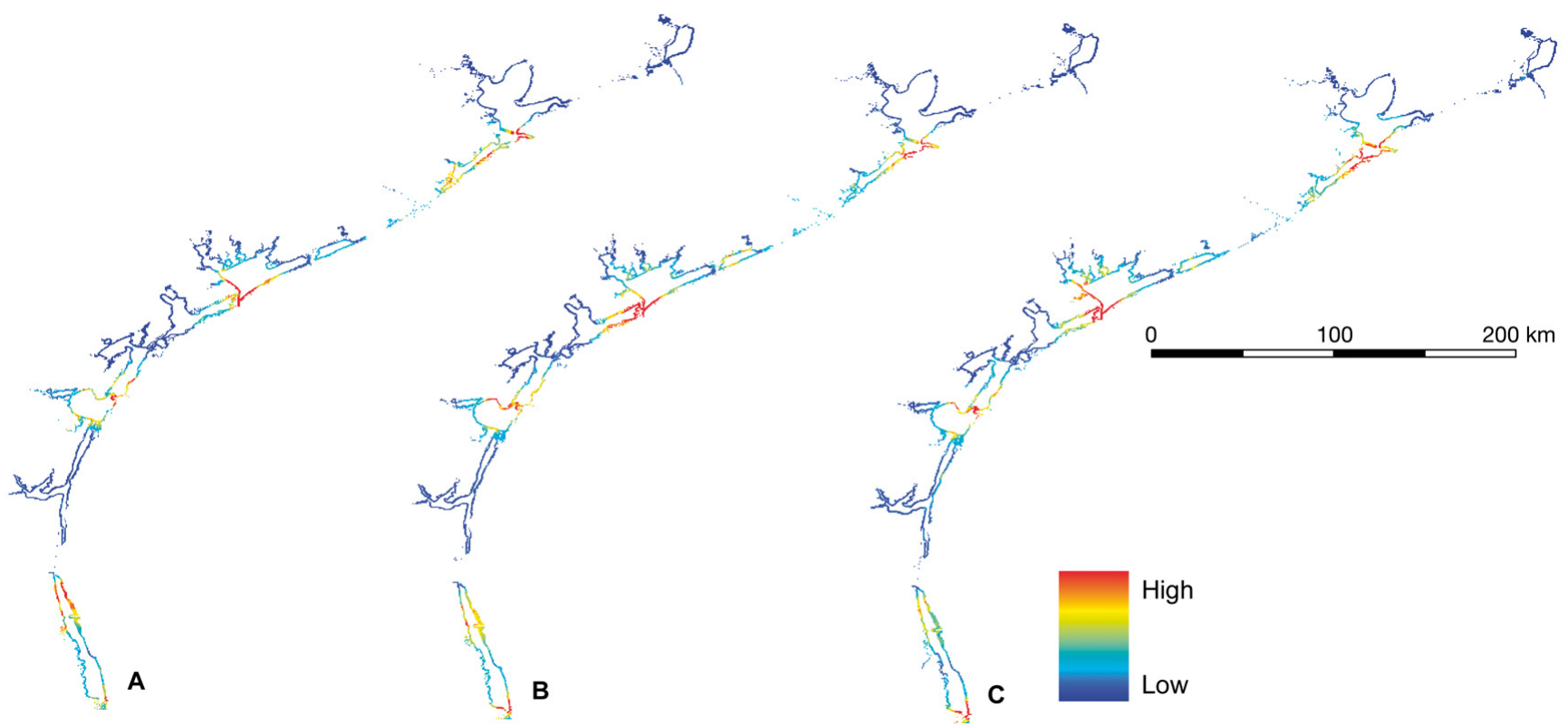

Fig. 8. Carcharhinus limbatus. Probability of capture maps of blacktip shark along the Texas coast as predicted by a boosted regression trees model for (A) spring, (B) fall, and (C) mean overall conditions. Predictions were restricted to areas within $1 \mathrm{~km}$ of the shoreline

bull sharks in Florida estuaries found similar patterns (Simpfendorfer et al. 2005, Heupel \& Simpfendorfer 2008). Selection of habitats based on salinity has been demonstrated in teleost fishes as a mechanism to reduce energetic costs of osmoregulation (Marais 1978) while permitting more energy for growth or reproduction. Laboratory experiments on euryhaline killifish
(Fundulus heterclitus) indicate that osmoregulation typically requires 6 to $10 \%$ of the total energy budget and fish select areas closest to their own osmolarity (Kidder 2006). Previous studies have hypothesized that use of low salinity waters is based on prey access or predator avoidance (Pillans \& Franklin 2004, Pillans et al. 2005). However, Heupel \& Simpfendorfer (2008)

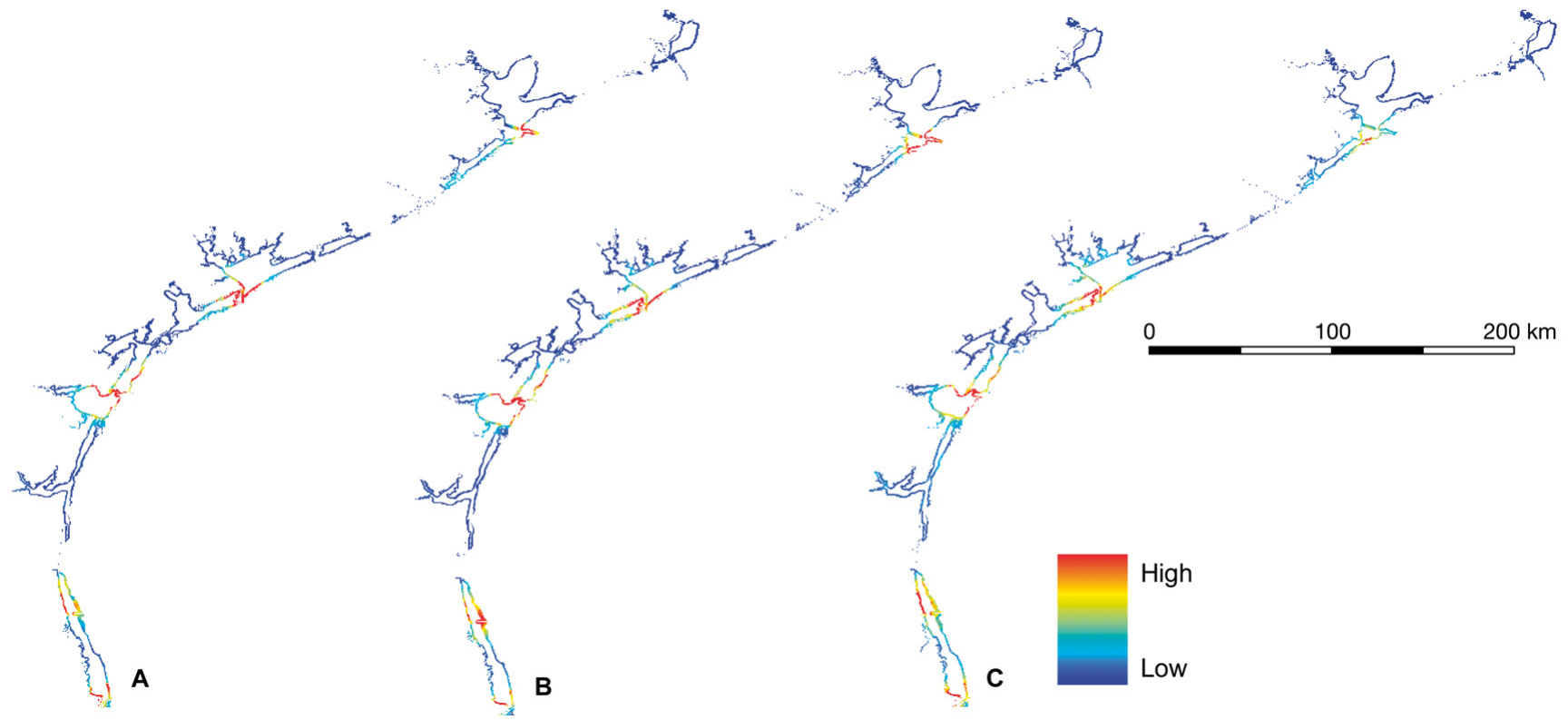

Fig. 9. Sphyrna tiburo. Probability of capture maps of bonnethead shark along the Texas coast as predicted by a boosted regression trees model for (A) spring, (B) fall, and (C) mean overall conditions. Predictions were restricted to areas within $1 \mathrm{~km}$ of the shoreline 
suggest that salinity preferences limit distribution patterns of juvenile bull sharks to between 7 and 20 psu. The present study expands these findings over a wider range of salinities ( 0 to $60 \mathrm{psu}$ ) for 3 shark species, and supports the hypothesis that sharks are using behavior to reduce metabolic demands of osmoregulation.

Temperature also strongly influenced distribution patterns of sharks. Few sharks were captured below $20^{\circ} \mathrm{C}$; however, catch rates for all species increased rapidly with increasing temperature between 20 and $33^{\circ} \mathrm{C}$ before declining again. Selection for warmer temperatures is also consistent with habitat use to maximize physiological performance as mean temperatures were warmer in samples where sharks were present, and this pattern was consistent across all months sampled. Like most other coastal species, juvenile blacktip sharks use estuaries as nursery habitat to reduce mortality rates (Beck et al. 2001), and the preference for increased temperatures may increase growth rates and boost metabolic rates (Heupel et al. 2007). In a study of blacktip sharks, Heupel and Simpfendorfer (2002) reported highest mortality rates during the first 15 weeks of life when animals are smallest and susceptible to the widest range of predators. Size of blacktip captured in the present study indicated that most were juveniles and habitat use may reflect a combination of rapid growth and lower mortality rates. Increasing catch rates of juvenile bull sharks with temperature was also reported by Simpfendorfer et al. (2005) while temperature was only moderately important for bonnethead sharks (Ubeda et al. 2009). Similarly, in this study temperature was not an important predictor of catch rates for bonnethead sharks as depth and distance to inlets most strongly influenced distribution patterns for this species. Temperature influences metabolic rate and determines rates of biochemical reactions and in this case, blacktip and bull sharks may be using behavioral thermoregulation as a means to increase growth rates. However, at extremely high temperatures (i.e. $>33^{\circ} \mathrm{C}$ ) catch rates of all 3 shark species were low, suggesting an upper thermal limit on habitats sharks can occupy.

Realized spatial distribution patterns integrate biological and environmental influences that ultimately determine habitat use patterns. Fry (1971) stated that the environment influences activities (i.e. movement) of an organism through metabolic effects and various environmental attributes interact in their effects on metabolism (Neill et al. 1994). Along the Texas coast, salinity and temperature were the greatest determinants of habitat use patterns and were moderated by climate patterns, river inflow, and water exchange with the Gulf of Mexico via tidal inlets. Although distribution patterns of bull sharks were not restricted to areas near tidal inlets, they are likely important com- ponents of habitat both as access corridors and as a source of oceanic-type waters. The brackish estuarine waters along the central Texas coast may represent the best integration of these factors contributing to higher probability of capture estimates in these areas. Probability of blacktip and bonnethead shark captures were highest in areas proximate to tidal inlets where waters are typically warm, near oceanic salinities, with access to deeper waters. Observed distribution patterns could also result from phenomena correlated with environmental patterns, such as prey or predator density which was not included in this study. However, Heupel and Hueter (2002) found no correlation between habitat selection and prey abundance of blacktip sharks in a Florida nursery suggesting other factors are the primary determinants of habitat use patterns.

Despite the utility of our modeling approach, there are some limitations to this methodology. Model evaluation indicated very good performance of the BRT at predicting independent testing data although the inference value may be limited due to high residual deviance in the models. However, data mining techniques can only find patterns that actually exist (Brodley et al. 1999), and the high residual deviance in the BRT models for all 3 species may suggest that some variables important in the habitat usage of these species may not have been included in the study. Biotic components, including prey availability, movement patterns (Papastamatiou et al. 2009) or philopatry (Hueter et al. 2005) of individuals were not considered in this study. Additionally, distributional models are correlational, thus they do not elucidate the mechanisms for species-habitat associations. Experimental approaches examining factors that influence habitat quality including growth rates or survivorship of individuals are necessary to determine causation (Valavanis et al. 2008). However, using our approach, we were able to simultaneously examine parameters and ranges of parameters related to habitat suitability laying the groundwork for future hypothesis-driven studies. Spatially explicit models permit applications that are not feasible with other approaches (Stoner et al. 2001) including (1) prediction of distribution patterns related to dynamic environmental patterns (i.e. temperature, salinity etc.), (2) identification of habitats needed for conservation of species, and (3) predictions of effects of habitat disturbance or alteration from either natural or anthropogenic causes.

Spatially explicit maps permit rapid identification and delineation of important habitats. For the shark species in the current study, areas along the central coast near tidal inlets provide highest probability of capture. Bull sharks extend considerable distances into estuaries where low or moderate salinity waters are available. All species were rare in hypersaline habitats 
(i.e. Upper Laguna Madre) and areas distant from access points to the Gulf of Mexico. Predicted distribution patterns were similar between spring and fall seasons for all 3 species, although the greatest environmental variation of salinity and temperature occurs between winter and summer seasons. Sharks were not sampled during winter conditions or July-August and further study is required to evaluate shark distribution patterns during this period. Despite the limited seasonal sampling, the Texas coast is unique in that the estuaries represent a natural gradient in salinity (from hypo- to hypersaline) and temperatures. This fact, coupled with the long time series of the present study (32 yr), enabled sampling over an extremely wide range of environmental conditions (Table 1). While additional sampling in winter and summer months is necessary to enable validated spatially-explicit predictions for these periods, our results predict similar patterns in the summer to observed spring-fall patterns and low probability of occurrence during winter for all 3 species primarily due to low temperatures.

Realized distribution patterns of these species may integrate both the spatial arrangement of habitats and the environmental conditions to determine habitat quality. In July 2005, the US Army Corps of Engineers dredged and reopened Packery Channel creating a new tidal connection to the Gulf of Mexico near Upper Laguna Madre and Corpus Christi Bay to increase water exchange, moderate salinities, and provide an additional ingress point for estuarine nekton (Reese et al. 2008). This management action may also improve habitat quality for sharks in this area by moderating salinities and providing additional access to these areas. Continued monitoring will be necessary to evaluate this impact.

Despite considerable interest, progress in identification of critical habitats for large mobile species (i.e. sharks) has been slow. This is due in part to the paucity of data over adequate spatial and temporal scales to characterize distribution patterns and empirical difficulties modeling species habitat distributions of rare animals (Rooper \& Martin 2009). Our long-term (32 yr), statewide assessment of 9 estuaries provides a first attempt at delineating critical habitat and identification of important environmental influences on shark habitat value in the northwestern Gulf of Mexico. In addition, we provide a framework in which to consider potential impacts of habitat alteration on shark habitat quality a priori, an important consideration in the light of continued human expansion and alteration of coastal habitats (Lotze et al. 2006). In Texas estuaries increasing temperatures and declining dissolved oxygen concentrations have been reported (Applebaum et al. 2005), and reduced freshwater inflow to the Texas coast is predicted due to global climate change (Ward
2009). Improving our ability to manage coastal shark stocks is critical as shark populations have declined in the Gulf of Mexico (Baum \& Myers 2004). Also, blacktip shark is an important component US commercial shark fishery (NMFS 2008) and are also heavily targeted in Mexican fisheries (Hueter et al. 2007). While blacktip shark is not currently overfished in the Gulf of Mexico (NMFS 2008), increasing fishing pressure or alteration of critical coastal habitats lends the potential for overexploitation of this species as well.

Long-term conservation requires identification and protection of critical ecosystems and the myriad of processes that influence habitat value (Levin \& Stunz 2005). Our results provide new insight into the habitat requirements of coastal sharks in the northwestern Gulf of Mexico and should provide practical information for conserving shark habitat and managing coastal resources. The development of spatially explicit models allows for prioritization of areas for conservation and provides insight into critical ecosystem attributes (i.e. salinity regimes) that merit protection. Areas with high probabilities of capture typically had warm temperatures and moderate salinities, highlighting the importance of both freshwater inflow and access to the Gulf of Mexico via tidal inlets for shark habitat suitability.

Acknowledgements. Funding for this study was provided by the United States Department of the Interior, US Geological Survey Cooperative Agreement no. 07HQAG0151, the Texas Research Development Fund, and the Faculty Excellence fund and Texas A\&M University - Corpus Christi. Gill net data for sharks was courtesy of Dr. Mark Fisher of the Texas Parks and Wildlife Department, Coastal Fisheries Division. We also thank Peter Melendez for his help with the spatial analyses in this project. Any use of trade, product, or firm names is for descriptive purposes only and does not imply endorsement by the US Government (e.g. the freeware R).

\section{LITERATURE CITED}

Applebaum S, Montagna PA, Ritter C (2005) Status and trends of dissolved oxygen in Corpus Christi Bay, Texas, USA Environ Monit Assess 107:297-311

Baum JK, Myers RA (2004) Shifting baselines and the decline of pelagic sharks in the Gulf of Mexico. Ecol Lett 7: 135-145

Beck MW, Heck KL Jr, Able KW, Childers DL and others (2001) The identification, conservation, and management of estuarine and marine nurseries for fish and invertebrates. Bioscience 51:633-641

Bethea DM, Hollensead L, Carlson JK (2006) Shark nursery grounds and essential fish habitat studies. Report to NOAA Fisheries, Highly Migratory Species Office, Panama City, FL

Brodley CA, Lane T, Stough TM (1999) Knowledge discovery and data mining. Am Sci 87:54-60

Carlisle AB, Starr RM (2009) Habitat use, residency, and seasonal distribution of female leopard sharks Triakis semi- 
fasciata in Elkhorn Slough, California. Mar Ecol Prog Ser 380:213-228

Elith J, Graham CH, Anderson RP, Dudik M and others (2006) Novel methods improve prediction of species distributions from occurrence data. Ecography 29:129-151

Elith J, Leathwick JR, Hastie T (2008) A working guide to boosted regression trees. J Anim Ecol 77:802-813

Friedman JH (2001) Greedy function approximation: a gradient boosting machine. Ann Stat 29:1189-1232

Friedman JH, Meulman JJ (2003) Multiple additive regression trees with application in epidemiology. Stat Med 22:1365-1381

Fry FEJ (1971) The effect of environmental factors on the physiology of fish. In: Hoar WS, Randall DJ (eds) Fish physiology, Vol 6, Academic Press, New York, NY, p 1-98

Grubbs RD, Musick JA (2007) Spatial delineation of summer nursery areas for juvenile sandbar sharks in Chesapeake Bay, Virginia. Am Fish Soc Symp 50:63-86

Hastie T, Tibshirani R, Friedman JH (2001) The elements of statistical learning: data mining, inference, and prediction. Springer, New York

Heithaus MR, Delius BK, Wirsing AJ, Dunphy-Daly MM (2009) Physical factors influencing the distribution of a top predator in a subtropical oligotrophic estuary. Limnol Oceanogr 54:472-482

Heupel MR, Hueter RE (2002) Importance of prey density in relation to the movement patterns of juvenile blacktip sharks (Carcharhinus limbatus) within a coastal nursery area. Mar Freshw Res 53:543-550

> Heupel MR, Simpfendorfer CA (2002) Estimation of survival and mortality of juvenile blacktip sharks, Carcharhinus limbatus, within a nursery area based on telemetry data. Can J Fish Aquat Sci 59:624-632

Heupel MR, Simpfendorfer CA (2008) Movement and distribution of young bull sharks Carcharhinus leucas in a variable estuarine environment. Aquat Biol 1:277-289

> Heupel MR, Carlson JK, Simpfendorfer CA (2007) Shark nursery areas: concepts, definition, characterization and assumptions. Mar Ecol Prog Ser 337:287-297

Hight BV, Lowe CG (2007) Elevated body temperatures of adult female leopard sharks, Triakis semifasciata, while aggregating in shallow nearshore embayments: Evidence for behavioral thermoregulation? J Exp Mar Biol Ecol 352:114-128

Hueter RE, Tyminski JP (2007) Species-specific distribution and habitat characteristics of shark nurseries in Gulf of Mexico waters off peninsular Florida and Texas. Am Fish Soc Symp 50:193-223

Hueter RE, Heupel MR, Heist EJ, Keeney DB (2005) Evidence of philopatry in sharks and implications for the management of shark fisheries. J Northwest Atl Fish Sci 35: 239-247

Hueter RE, Castillo-Genz JL, Marquez-Farias JF, Tyminski JP (2007) The use of Laguna Yalahau, Quintana Roo, Mexico as primary nursery for the blacktip shark. Am Fish Soc Symp 50:345-364

Kidder GW III, Petersen CW, Preston RL (2006) Energetics of osmoregulation: II. water flux and osmoregulatory work in the euryhaline fish, Fundulus heteroclitus. J Exp Zool Part A. Comparative Experimental Biology 305A:318-327

> Lane JQ, Raimondi PT, Kudela RM (2009) Development of a logistic regression model for the prediction of toxigenic Pseudo-nitzschia blooms in Monterey Bay, California. Mar Ecol Prog Ser 383:37-51

Leathwick JR, Elith J, Francis MP, Hastie T, Taylor P (2006) Variation in demersal fish species richness in the oceans surrounding New Zealand: an analysis using boosted regression trees. Mar Ecol Prog Ser 321:267-281
Leathwick JR, Elith J, Chadderton WL, Rowe D, Hastie T (2008) Dispersal, disturbance, and the contrasting biogeographies of New Zealand's diadromous and nondiadromous fish species. J Biogeogr 35:1481-1497

- Levin PS, Stunz GW (2005) Habitat triage for exploited fishes: Can we identify essential 'Essential Fish Habitat?'. Estuar Coast Shelf Sci 64:70-78

- Lotze HK, Lenihan HS, Bourque BJ, Bradbury RH and others (2006) Depletion, degradation, and recovery potential of estuaries and coastal seas. Science 312:1806-1809

Marais JFK (1978) Routine oxygen consumption of Mugil cephalus, Liza dumerili and L. richardsoni at different temperatures and salinities. Mar Biol 50:9-16

Martinez-Andrade F, Fisher M, Bowling B, Balboa B (2009) Marine resource monitoring operations manual. Texas Parks and Wildlife Department Coastal Fisheries Division

Matern SA, Cech JJ, Hopkins TE (2000) Diel Movements of bat rays, Myliobatis californica, in Tomales Bay, California: evidence for behavioral thermoregulation? Environ Biol Fishes 58:173-182

McCandless T, Kohler NE, Pratt HL Jr (2007) Species specific shark nursery habitat summary tables. In: McCandless CT, NE Kohler, and HL Pratt Jr (eds) Sharks nursery grounds of the Gulf of Mexico and the East Coast waters of the United States. Am Fish Soc Symp 50, Bethesda, MD, p 365-390

> Morrissey JF, Gruber SH (1993) Habitat selection by juvenile lemon sharks, Negaprion brevirostris. Environ Biol Fishes 38:311-319

Musick JA, Burgess G, Cailliet G, Camhi M, Fordham S (2000) Management of sharks and their relatives (Elasmobranchii). Fisheries 25:9-13

Neill WH, Miller JM, Van Der Veer HW, Winemiller KO (1994) Ecophysiology of marine fish recruitment: a conceptual framework for understanding interannual variability. Neth J Sea Res 32:135-152

NMFS (National Marine Fisheries Service) (2008) 2008 stock assessment and fishery evaluation (SAFE) report for Atlantic highly migratory species. National Marine Fisheries Service, National Oceanic and Atmospheric Administration, US Dept Commerce, Silver Spring, MD

Ortega L, Heupel M, Beynen P, Motta P (2009) Movement patterns and water quality preferences of juvenile bull sharks (Carcharhinus leucas) in a Florida estuary. Environ Biol Fishes 84:361-373

Papastamatiou YP, Lowe CG, Caselle JE, Friedlander AM (2009) Scale-dependent effects of habitat on movements and path structure of reef sharks at a predator-dominated atoll. Ecology 90:996-1008

> Parisien MA, Moritz MA (2009) Environmental controls on the distribution of wildfire at multiple spatial scales. Ecol Monogr 79:127-154

Parsons GR, Carlson JK (1998) Physiological and behavioral response to hypoxia in the bonnethead shark, Sphyrna tiburo: routine swimming and respiratory regulation. Fish Physiol Biochem 19:189-196

Parsons GR, Hoffmayer ER, Taylor CM (2005) Seasonal changes in the distribution and relative abundance of the Atlantic sharpnose shark Rhizoprionodon terraenovae in the north central Gulf of Mexico. Copeia 2005:914-920

> Pillans RD, Franklin CE (2004) Plasma osmolyte concentrations and rectal gland mass of bull sharks Carcharhinus leucas, captured along a salinity gradient. Comp Biochem Physiol A 138:363-371

Pillans RD, Good JP, Anderson WG, Hazon N, Franklin CE (2005) Freshwater to seawater acclimation of juvenile bull sharks (Carcharhinus leucas): plasma osmolytes and 
$\mathrm{Na}+/ \mathrm{K}+-\mathrm{ATP} a \mathrm{se}$ activity in gill, rectal gland, kidney and intestine. Comp Biochem Physiol B 175:37-44

Reese MM, Stunz GW, Bushon AM (2008) Recruitment of estuarine-dependent nekton through a new tidal inlet: the opening of Packery Channel in Corpus Christi, TX, USA. Estuaries Coasts 31:1143-1157

Rooper CN, Martin MH (2009) Predicting presence and abundance of demersal fishes: a model application to shortspine thornyhead Sebastolobus alascanus. Mar Ecol Prog Ser 379:253-266

Saveliev AA, Mukharamova SS, Chizhikova NA, Budgey R, Zuur AF (2007) Spatially continuous data analysis and modelling. In: Zuur AF, Ieno EN, Smith GM (eds) Analysing ecological data. Springer, New York, NY, p 341-372

Simpfendorfer C, Freitas G, Wiley T, Heupel M (2005) Distribution and habitat partitioning of immature bull sharks (Carcharhinus leucas) in a southwest Florida estuary. Estuaries Coasts 28:78-85

Sing T, Sander O, Beerenwinkel N, Lengauer T (2005) ROCR: visualizing classifier performance in R. Bioinformatics 21: 3940-3941

Stoner AW (2003) What constitutes essential nursery habitat for a marine species? A case study of habitat form and function for queen conch. Mar Ecol Prog Ser 257:275-289

Stoner AW, John PM, Jeffrey PP (2001) Spatially explicit

Editorial responsibility: Hans Heinrich Janssen,

Oldendorf/Luhe, Germany analysis of estuarine habitat for juvenile winter flounder: combining generalized additive models and geographic information systems. Mar Ecol Prog Ser 213:253-271

Thorson TB, Cowan CM, Watson DE (1973) Body fluid solutes of juveniles and adults of the euryhaline bull shark Carcharhinus leucas from FW and saline environments. Copeia 4:29-42

Ubeda AJ, Simpfendorfer CA, Heupel MR (2009) Movements of bonnetheads, Sphyrna tiburo, as a response to salinity change in a Florida estuary. Environ Biol Fishes 84: 293-303

Valavanis VD, Pierce GJ, Zuur AF, Palialexis A, Saveliev A, Katara I, Wang J (2008) Modelling of essential fish habitat based on remote sensing, spatial analysis and GIS. Hydrobiologia 612:5-20

Ward G (2009) Water Resources. In: Schmandt J, Clarkson J, North GR (eds) The impact of global warming on Texas. University of Texas Press, Austin

Whaley SD, Burd JJ, Robertson BA (2007) Using estuarine landscape structure to model distribution patterns in nekton communities and in juveniles of fishery species. Mar Ecol Prog Ser 330:83-99

Worm B, Sandow M, Oschlies A, Lotze HK, Myers RA (2005) Global patterns of predator diversity in the open oceans. Science 309:1365-1369

Submitted: July 30, 2009; Accepted: February 17, 2010 Proofs received from author(s): May 7, 2010 